\title{
INCENTIVE SPIROMETRY AND DEEP BREATHING EXERCISE PREFER TO PREVENT DECREASED OF LUNG VITAL CAPASITY AS GOOD AS DEEP BREATHING EXERCISE POST CORONARY ARTERY BYPASS GRAFT PHASE I
}

\author{
Sabirin Berampu, Indra Alamsyah \\ Program Studi Fisioterapi Fakultas Keperawatan dan Fisioterapi \\ Institut Kesehatan Medistra, Lubuk Pakam \\ Email: sabirinbrampu@yahoo.co.id
}

\begin{abstract}
Coronary artery bypass graft (CABG) is a procedure to remove the blood vessels from internal mammary artery, radial artery or vein saphenus and to the surface of the heart to create a bypass in coronary artery narrowing. Data taken from the patients with heart disease from medical department of rehabilitation H.Adam Malik Medan who undergoing coronary bypass graft surgery. From 73 patients with post-cardiac surgery who were referred to the Medical Rehabilitation, 49 people were post-CABG (in 2010), and 57 people in 2011. General anesthesia, diaphragmatic dysfunction, abdominal distension, changes in chest wall, surgical wound, pleural effusion, pain and dysfunction of the respiratory muscles, may lead to reduction in lung vital capasity of up to 55\% post operative. Intervention were incentive spirometry and breathing exercise. The purposes of this study is knowing whether the intervention incentive spirometry and breathing exercise can more minimize the decline in lung capasity than breathing exercise intervention only on post-CABG in phase I. Experimental research with non-probability sampling two group pre test and post test design. Subjects of group $I(n=9)$ receive incentive spirometry (IS) and deep breathing exercises (DBE), while group II $(n=9)$ receive only a deep breathing exercise. Data analysis with paired samples t-test suggested the mean value of vital capasity (VC) from group I (IS and DBE) was $73.78 \%$ (pre op) after 6 days postoperatively decreased to 59.56, average decline in $14.22, P=0.002$. While the VC on group II (DBE) was 74.11 after 6 days postoperatively decreased to 55.78. Average reduction was $18,33, p$ value $=0.0001$. There was no significantly differences between group $I$ and group II from statistical analysis Independent $t$-test, with $p$-value $=0.512$ $(p>0.05)$. Conclusions of this study: There was a significant effect of incentives spirometry and deep breathing exercises in preventing the decrease of lung vital capasity in post-CABG patients, There was a significant influence provision of deep breathing exercises in preventing the decrease of lung vital capasity, There were no significant differences between treatment combinations of incentive spirometry and deep breathing exercises with deep breathing exercises only in preventing the decrease of lung vital capasity in post-CABG, with a $p$-value $=0.512$.
\end{abstract}

Keywords: Deep breathing exercises, incentive spirometry, lung vital capasity.

\section{Pendahuluan}

Penyakit jantung koroner (PJK) menunjukkan jumlah yang cukup berarti sekitar 1.500 .000 orang setiap tahunnya terjadi di Amerika, sekitar 500.000 orang meninggal sebelum sampai di rumah sakit (Bahri. 2009). Penyakit ini merupakan penyebab kematian nomor satu di Indonesia (Bahri. 2009). Meskipun secara nasional belum ada data pasti tentang PJK di Indonesia, tampaknya kecenderungan telah terjadi peningkatan penderita yang dirawat di Rumah Sakit pemerintah maupun 
swasta. Data dari bagian Cardiac Vascular Care Unit ( CVCU) RSUP H.Adam Malik Medan, jumlah pasien PJK yang di rawat 613 orang dalam tahun 2010.

Data dari bagian rehabilitasi medis RSUP H.Adam Malik Medan menunjukkan penderita penyakit jantung koroner yang menjalani operasi bypass graft atau CABG (Coronarya Arteri Bypass Graft), dari 73 pasien pasca operasi jantung yang dirujuk ke Rehabilitasi Medik, 49 orang adalah pasca CABG ( tahun 2010), dan 57 orang pada tahun 2011 ( Adam malik, 2011).

Masalah yang timbul pada fase awal pasca operasi adalah; nyeri sekitar dada, sesak napas, sekret sulit untuk dikeluarkan dan keterbatasan aktivitas. Efek dari anaestesia, nyeri luka operasi, posisi supin lying, respirasi yang monoton dan dangkal akan menyebabkan penimbunan secret di saluran napas atau atelektasis, hal ini menyebabkan penurunan volume paru dan fungsi paru (Nurbasuki. 2010).

Program rehabilitasi jantung atau Fisioterapi secara umum bertujuan untuk memulihkan keadaan penderita sesegera mungkin agar sembuh atau kembali pada keadaan sebelum sakit. Mampu mandiri dalam aktifitas seharihari bahkan kembali bekerja menjadi manusia yang produktif ( Dede, et al. 2003).

Program rehabilitasi jantung dikelompokkan menjadi 3 fase yaitu : Fase I (Fase rawat inap selama $7-14$ hari), Fase II (Fase rawat jalan sekitar 4 hingga 8 minggu), dan (3) Fase III ( Fase pemeliharaan selama 3-6 bulan ). Penelitian ini ditujukan pada fase I yaitu saat pasien dirawat di ICCU dan CVCU.
Tujuan fisioterapi secara umum pada fase I adalah: mempertahankan atau meningkatakan fungsi paru salah satunya vital capasity paru, mengurangi nyeri dan spasme otot, mencegah komplikasi bed rest dan mengembalikan fungsi jantung. (Dede, et al. 2003)

Gangguan fungsi paru pada pasca operasi thorak dan abdomen penyebabnya sangat komplek antara lain: Anastesi umum, disfungsi diafragma, distensi abdomen, perubahan dinding dada, luka operasi, efusi pleura, rasa nyeri dan disfungsi otot- otot pernapasan. Dari semua hal tersebut akan berkontribusi untuk terjadinya atelektasis dan penurunan vital capasity paru, sehingga fungsi paru berkurang hingga $55 \%$ setelah operasi thorak (Gosselink. 2005 ).

Program yang diberikan selama ini di Rehabilitasi Jantung RSUP H.Adam Malik adalah Chest Fisioterapi konvensional tanpa menggunakan alat atau media, antara lain : latihan batuk efektif, huffing, puslip breating exercise, percusi, vibrasi, latihan passiv-aktif, latihan transfer dan ambulasi. (Standar pelayan RSUP A.Malik 2008). Peneliti ingin menambahkan satu tindakan yaitu pemberian insentif spirometri pada pasien pasca operasi CABG, untuk mencegah penurunan vital capasity volume paru.

Insentif spirometri adalah : Suatu alat mekanis yang didesain untuk menstimulasi inspirasi maksimal melalui penggunaan umpan balik (feedback). Insentif spirometri memberikan fasilitasi neuro fisiologi respirasi melalui rangsangan eksternal dan internal, propioseptik dan taktil sehingga memberikan efek terhadap pola pernafasan, ekspansi thorak, meminimalisasi penumpukan cairan di 
paru-paru, dan meningkatkan kekuatan otot-otot respirasi. Semuanya itu akan berimplikasi terhadap peningkatan volume dan Vital capasity paru pada pasca CABG (Overend.et al.2001).

Penurunan vital capasity paru dapat terjadi pada pasca operasi besar maupun akibat dari suatu penyakit kronik, problem penurunan vital capasity paru akhir-akhir ini mendapat perhatian serius terutama pada paska bedah thorak dan abdomen, komplikasi paru pasca CABG selain meningkatkan biaya perawatan juga beresiko terhadap peningkatan angka kematian (mortality rate) (Nurbasuki.2010).

Faktor-faktor yang mempengaruhi ventilasi paru antara lain adalah : gaya gravitasi, elastisitas paru, sangkar torak dan otot-otot pernapasan. Dimana hal ini memungkinkan untuk terjadinya perbedaan tekanan intrapleural dan menyebabkan perubahan volume dan kapasitas paru. Volume paru terdiri dari, Tidal Volume (IV), Inspiratory Reserve Volume (IRV), Expiratory Reserve Volume (ERV), dan Residual Volume (RV). Kombinasi keempat volume tersebut akan membentuk kapasitas paru yaitu kapasitas inspirasi, kapasitas residu fungsional, kapasitas vital, kapasitas total paru (Ganong. W. F., 2003).

Pada pasien pasca operasi CABG posisi awal adalah terlentang, hal ini akan menyebabkan lengkungan diafragma akan terdesak oleh organ viscera pada perut hal ini akan menyulitkan pasien untuk bernapas. Dalam suatu journal penelitian yang bertujuan untuk menentukan pengaruh posisi pada aktivitas expiratory otot abdominal menyebutkan bahwa ERV nilainya lebih kecil pada posisi terlentang dibanding posisi lain. VC dalam posisi berdiri, duduk adalah lebih besar dari posisi yang terlentang, dan
IRV pada posisi duduk dan posisi berdiri adalah lebih besar dari posisi halflying (Gosselink, 2005).

Latihan pernapasan dan mobilisasi sedini mungkin sangat efektif untuk mengurangi atelektasis, radang paru dan komplikasi paru lainnya pada pasien pasca operasi CABG. Sebagian besar literatur mengatakan Intervensi fisioterapi berupa breating exercise pada pre dan pasca operasi akan mengurangi komplikasi atelektasis dan meningkatkan volumen paru (Sema, et.al.2006).

Metode yang digunakan untuk meningkatkan volumen dan vital capasity paru adalah Latihan ketahanan dan penguatan otot-otot pernapasan, latihan sikap (postural exercise). Pada tahap awal latihan pasien pasca operasi dapat diberikan dengan bantuan alat berupa insentif spirometri dikombinasikan dengan latihan mobilisasi (Irawati.1996). Sejumlah studi terbaru ditemukan penambahan insentif spirometri dan latihan napas dalam telah terbukti meningkatkan fungsi paru dan menurunkan komplikasi paru. Isentif spirometri merupakan perangkat yang baik dalam memberikan umpan balik visual dalam latihan pernapasan (Sema. et al, 2006).

Penelitian yang dilakukan oleh Guimaraes, et al, 2006 di Brazil menyimpulkan bahwa penambahan insentif spirometri pada pasien pasca bedah torak, efektif untuk mencegah komplikasi paru dan lama perawatan di rumah sakit. Sementara penelitian yang dilakukan oleh (Gosselink.et al, 2005) di Belgia menyatakan bahwa insentif spirometri tidak efektif dalam mencegah atelektasis pada pasca operasi thorak dan abdomen. Dengan insentif spirometri diharapkan dapat meningkatkan volume dan vital 
capasity paru dan kebutuhan oksigen akan terpenuhi sehingga kapasitas fisik makin meningkat dan proses pemulihan lebih baik. Di sisi lain masih adanya kontroversi perlu tidaknya pemberian latihan insentif spirometri pada penderita pasca operasi CABG di Rumah sakit.

Berdasarkan uraian di atas penulis tertarik untuk meneliti perbedaan pemberian intervensi insentif spirometri dan breathing exercise dengan breathing exercise konvensional dalam meminimalisasi penurunan vital capasity paru pada pasca operasi CABG fase I. Dengan insentif spirometri diharapkan dapat meningkatkan volume dan vital capasity paru dan kebutuhan oksigen akan terpenuhi sehingga kapasitas fisik makin meningkat dan proses pemulihan lebih baik. Tujuan penelitian, adalah mengetahuai intervensi insentif spirometri dan breathing exercise menghambat penurunan vital capasity paru pada pasien pasca CABG fase I, mengetahui intervensi breathing exercise menghambat penurunan vital capasity paru pada pasien pasca CABG fase I, mengetahui intervensi insentif spirometri dan breating exercise lebih menghambat penurunan vital capacity paru dibanding dengan hanya intervensi breathing exercise pada pasca CABG fase I

\section{METOde PENELITIAN}

Jenis penelitian ini adalah penelitian metode kuantitatif jenis eksperimental, dengan rancangan penelitian yang digunakan adalah pre test and post test group design. Untuk mengetahui efek pemberian terapi combinasi Insentif spirometri dengan breathing exercise dan pemberian hanya pemberian breathing exercise di ICCU dan CVCU RSUP H. adam malik. Subyek penelitian dibagi dua kelompok, Kelompok I adalah subyek yang mendapatkan perlakuan insentif spirometri dan breathing exercise sedangkan kelompok II adalah subyek yang mendapatkan pelayanan fisioterapi sesuai dengan standar berupa breating exercise. Data akan diolah dengan menggunakan $U \mathrm{Ui}$ statistik deskriptif untuk menganilisis umur, jenis kelamin , pekerjaan ,faktor resiko, Uji normalitas data dengan Saphiro Wilk Test, untuk mengetahui data berdistribusi normal nilai signifikan lebih besar dari 0,05 ( $\mathrm{P}>0,05)$, Uji homogenitas data dengan Leven,s Test, untuk mengetahui sebaran data bersifat homogen dengan nilai signifikansi lebih besar dari 0,05 ( $P>0,05$ ).

Jika datanya berdistribusi normal, maka digunakan pengujian hipotesis 1 dengan menggunakan paired sample $t$ test untuk menguji penurunan vital capasity paru atau nilai prosentase prediksi FVC sebelum (pre operasi dengan setelah perlakuan ( pasca operasi) dengan perlakuan insentif spirometri dan Breating exercise (kel.I). Pengujian hipotesis 2 yaitu: perbedaan nilai FVC paru sebelum perlakuan dengan setelah perlakuan Breathing exercise (kel.II) sebelum dan setelah perlakuan. Untuk pengujian ini digunakan Pired sample t-test. Pengujiann hipotesis 3 yaitu: Untuk mengetahui perbedaan penurunan nilai FVC kelompok (I) dengan penurunan nilai FVC kelompok (II) setelah mendapatkan perlakuan selama 6 hari, untuk pengujian ini digunakan Independenty sample t-test.

Jika datanya tidak berdistribusi normal, maka digunakan pengujian hipotesis 1 dengan menggunakan Wilcoxon match pairs test untuk menguji penurunan vital capasity paru 
atau nilai prosentase prediksi FVC sebelum (pre operasi dengan setelah perlakuan ( pasca operasi) dengan perlakuan insentif spirometri dan Breating exercise ( kel.I) Pengujian hipotesis 2 yaitu: perbedaan nilai FVC paru sebelum perlakuan dengan setelah perlakuan Breathing exercise (kel.II) sebelum dan setelah perlakuan. Untuk pengujian ini digunakan Wilcoxon match pairs test. Pengujiann hipotesis 3 yaitu: Untuk mengetahui perbedaan penurunan nilai FVC kelompok (I) dengan penurunan nilai FVC kelompok (II) setelah mendapatkan perlakuan selama 6 hari, untuk pengujian ini digunakan Mann whitney $U$ test

\section{HASIL PENELITIAN.}

Penelitian ini dilakukan di Instalasi Rehabilitasi Medik unit fisioterapi, ICCU dan CVCU RSUP H. Adam Malik Medan yang terletak di Jalan Bunga Lau nomor 17 Medan, Sumatera Utara. Populasi penelitian ini adalah pasien pasca CABG yang dirawat di Intensive cardiac care unit (ICCU) dan Cardiac vascular care unit (CVCU) RSUP H.Adam Malik.

Lama periode pengambilan sampel, yaitu selama 3 bulan sejak tanggal 25 januari sampai 20 April 2012 , terdapat 18 orang yang memenuhi kriteria inklusi dan eksklusi sehingga diikutkan dalam penelitian ini.

\subsection{Deskripsi Karakteristik Subjek Penelitian}

Gambaran karakteristik subyek penelitian ini disajikan pada tabel 1.1 Tabel 1.1.

Gambaran karakteristik demografi subyek penelitian

\begin{tabular}{|c|c|c|c|c|}
\hline $\begin{array}{l}\mathrm{N} \\
\mathrm{O}\end{array}$ & $\begin{array}{l}\text { Karakteristik } \\
\text { subyek }\end{array}$ & Frekuensi & $\begin{array}{l}\text { Kelompok } \\
\text { I (BE+IS) }\end{array}$ & $\begin{array}{l}\text { KelompokII } \\
\text { (BE) }\end{array}$ \\
\hline & $\mathrm{N} \%$ & $18(100 \%)$ & $9(50 \%)$ & $9(50 \%)$ \\
\hline \multicolumn{5}{|c|}{1 Jenis kelamin(\%) } \\
\hline & ki-laki & $15(83 \%)$ & $8(89 \%)$ & $7(88 \%)$ \\
\hline & $\begin{array}{l}\text { rempuan } \\
\text { nur (\%) }\end{array}$ & $3(17 \%)$ & $1(11 \%)$ & $2(22 \%)$ \\
\hline & - 50 tahun & $4(22 \%)$ & $1(11 \%)$ & $3(33,3 \%)$ \\
\hline & -60 tahun & $10(56 \%)$ & $7(78 \%)$ & $3(33,3 \%)$ \\
\hline
\end{tabular}

$\begin{array}{llll}61-70 \text { tahun } & 4(22 \%) & 1(11 \%) & 3(33,3 \%) \\ \text { Mean }=56,00 \mathrm{SD}= & & \\ 3,77 & & \\ 3 \text { Tinggi badan(\%) } & & & \\ 141-150 \mathrm{Cm} & 4(22 \%) & 1(11 \%) & 2(22,2 \%) \\ 151-160 \mathrm{Cm} & 10(56 \%) & 7(78 \%) & 3(33,3 \%) \\ 161-170 \mathrm{Cm} & 4(22 \%) & 1(11 \%) & 4(44,5 \%) \\ \text { Mean }=158,67 & & & \\ \text { SD }=3,77 & & & \\ 4 \text { Berat badan(\%) } & & & \\ 41-50 \mathrm{~kg} & 6(33 \%) & 2(22,2 \%) & 4(44,5 \%) \\ 51-60 \mathrm{~kg} & 9(50 \%) & 6(66,7 \%) & 3(33,3 \%) \\ 61-70 \mathrm{~kg} & 3(17 \%) & 1(11,1 \%) & 2(22,2 \%) \\ \text { Mean }=57,00 & & & \\ \text { SD }=5,98 & & & \end{array}$

\subsection{Gambaran Nilai vital capacity (VC) sebelum dan setelah perlakuan kelompok I}

Sebelum mendapatkan kombinasi insentif spirometri dan breathing exercise (pre operasi), nilai rerata prosen prediksi vital capasity adalah $73,78 \pm 13,51$ dengan nilai terendah 55 dan tertinggi adalah 90 . Setelah mendapatkan terapi combinasi (pasca operasi) nilai rerata menurun menjadi $59,56 \pm 8,53$ dengan nilai terendah 48 dan tertinggi adalah 71 , hasilnya tertera pada tabel 1.2di bawah ini.

Tabel 1.2

Gambaran skor persen prediksi Vital capasity sebelum dan setelah perlakuan Pada Kelompok I

\begin{tabular}{|c|c|c|c|c|c|}
\hline Skor VC & $\mathbf{s}$ & $\begin{array}{c}\text { Mini } \\
\text { mum }\end{array}$ & $\begin{array}{l}\text { Maxi } \\
\text { mum }\end{array}$ & Mean & SD \\
\hline $\begin{array}{l}\text { Sebelum } \\
\text { Perlakuan } \\
\text { (pre } \\
\text { operasi) }\end{array}$ & 9 & 55 & 90 & 73,78 & 13,51 \\
\hline $\begin{array}{l}\text { Setelah } \\
\text { Perlakuan } \\
\text { (pasca } \\
\text { operasi) }\end{array}$ & 9 & 48 & 71 & 59,56 & 8,53 \\
\hline
\end{tabular}

\subsection{Gambaran Nilai VC Sebelum dan Setelah Perlakuan pada Kelompok II. \\ Sebelum mendapatkan terapi} breathing exercise (pre operasi), nilai rerata prosen prediksi VC adalah 74,11 $\pm 8,31$ dengan nilai terendah 60 dan tertinggi adalah 86. Setelah mendapatkan terapi breathing exercise (pasca operasi) nilai rerata menjadi 
$55,78 \pm 7,99$ dengan nilai terendah 48 dan tertinggi adalah 69 .

\section{Tabel 1.3}

Gambaran skor persen prediksi VC sebelum dan setelah perlakuan breathing exercise pada kelompok II

\begin{tabular}{|c|c|c|c|c|c|}
\hline Skor FVC & $\mathrm{s}$ & $\begin{array}{c}\text { Minim } \\
\text { um }\end{array}$ & $\begin{array}{c}\text { Maximu } \\
\mathrm{m}\end{array}$ & Mean & SD \\
\hline $\begin{array}{l}\text { Sebelum } \\
\text { Perlakuan } \\
\text { (pre } \\
\text { operasi) }\end{array}$ & 9 & 60 & 86 & 74,11 & 8,31 \\
\hline $\begin{array}{l}\text { Setelah } \\
\text { Perlakuan } \\
\text { (pasca } \\
\text { operasi) }\end{array}$ & 9 & 48 & 69 & 55,78 & 7,99 \\
\hline
\end{tabular}

\section{$1.4 \mathrm{Uji}$ Normalitas data Vital} capasity Pasien CABG

Uji normalitas digunakan untuk mengetahui apakah data dari sampel yang diambil memiliki distribusi yang normal atau tidak, sebagai prasyarat untuk menentukan uji statistik. Pada pengujian ini menggunakan uji Shapiro-wilk, data vital capasity (vc) yang diuji sebelum, setelah perlakuan dan selisih sebelum dan setelah perlakuan. Kriteria pengujian apabila nilai $P>0,05$, maka data berdistribusi normal. Sedangkan bila nilai $P<0,05$, maka data tidak berdistribusi normal, yang hasilnya tertera pada tabel 1.4

Tabel 1.4

Hasil Uji Normalitas Data VC pada Sebelum dan Sesudah Insentif Spirometri dan Breathing Exercise.

Berdasarkan table diatas dapat dilihat bahwa data masing-masing kelompok sebelum dan setelah

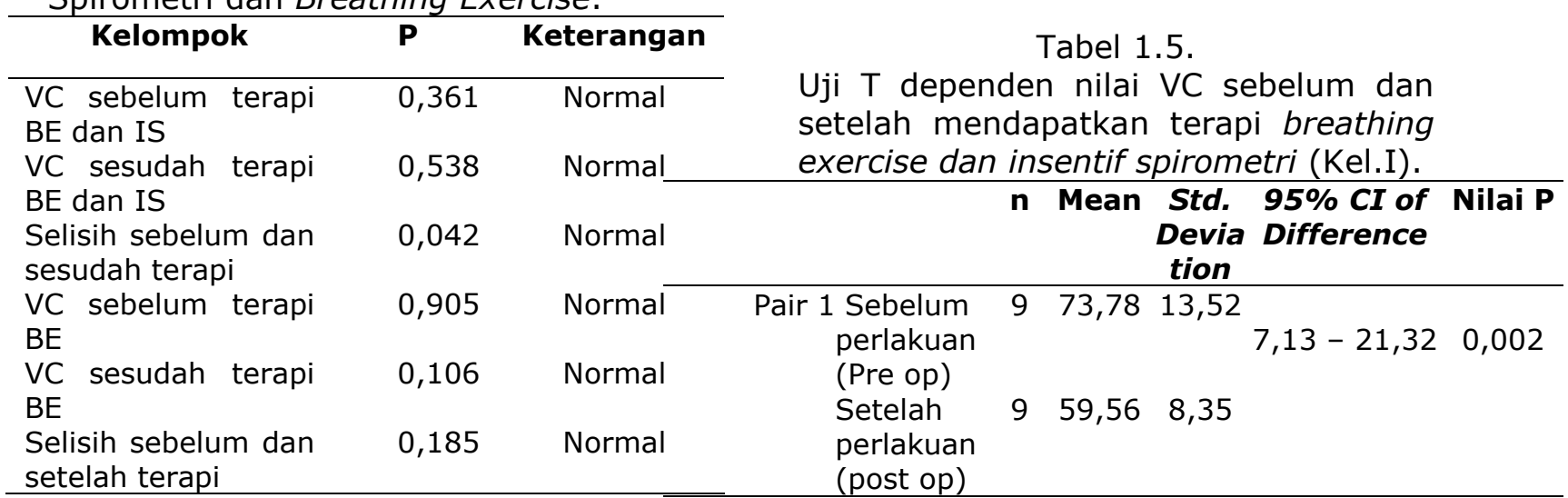

perlakuan memiliki nilai $P$ lebih besar dari 0,05 $(P>0,05)$, maka kedua data dianggap berdistribusi normal. Sedangkan selisih kedua perlakuan nilai $P$ lebih besar dari $0,05(P>0,05)$, yang berarti data berdistribusi normal.

\section{$1.5 \mathrm{Uji}$ hipotesis I. Pemberian} breathing exercise dan insentif spirometri dalam meminimalisasi penurunan vital capasity paru.

Tabel 1.5. memperlihatkan bahwa rerata nilai VC pada 9 subjek di awal penelitian (sebelum operasi) adalah 73,78 (SD 13,52). Setelah mendapatkan terapi kombinasi breathing exercise dan insentif spirometri selama 6 hari atau 6 kali pertemuan (sesudah operasi), penurunan nilai reratanya menjadi 59,56 (SD 8,35).

Rerata penurunan nilai VC awal dan setelah enam hari diterapi dengan breathing exercise dan insentif spirometri adalah 14,22. Analisis statistik dengan $u j i \quad T$ dependen menunjukkan nilai $P=0,002$, maknanya: Bila tidak ada perbedaan rerata nilai VC sebelum dan setelah perlakuan, terdapat kemungkinan sebesar 0,002 (0,2\%). Karena nilai $\rho<0,05$ disimpulkan bahwa ada perbedaan yang signifikan dalam hal rerata nilai VC sebelum perlakuan dan setelah 6 hari mendapatkan terapi kombinasi breathing exercise dan insentif spirometri

Tabel 1.5.

Uji T dependen nilai VC sebelum dan setelah mendapatkan terapi breathing exercise dan insentif spirometri (Kel.I).

\subsection{Uji hipotesis II. Pemberian breathing exercise dalam}




\section{meminimalisasi penurunan vital capasity paru.}

Tabel 1.6 memperlihatkan bahwa rerata nilai VC pada 9 subjek di awal penelitian (sebelum operasi) adalah 74,11 (SD 8,31). Setelah mendapatkan terapi kombinasi breathing exercise dan insentif spirometri selama 6 hari atau 6 kali pertemuan (sesudah operasi), penurunan nilai reratanya menjadi 55,78 (SD 7,99).

Rerata penurunan nilai VC awal dan setelah enam hari diterapi dengan breathing exercise dan insentif spirometri adalah 18,33. Analisis statistik dengan uji $T$ dependen menunjukkan nilai $P=0,000$. Karena nilai $\rho<0,05$ disimpulkan bahwa ada perbedaan yang signifikan dalam hal rerata nilai VC sebelum perlakuan dan setelah 6 hari mendapatkan terapi combinasi breathing exercise dan insentif spirometri

\section{Tabel 1.6}

Uji T dependen nilai VC sebelum dan setelah mendapatkan terapi breathing exercise (Kel.II).

\begin{tabular}{ccccc}
\hline & n Mean $\begin{array}{c}\text { Std. } \\
\text { Devia } \\
\text { tion }\end{array}$ & $\begin{array}{c}\text { 95\% CI of } \\
\text { Difference }\end{array}$ & $\begin{array}{c}\text { Nilai } \\
\text { P }\end{array}$ \\
\hline Pair 1 Sebelum & 94,11 & 8,31 & & \\
$\begin{array}{c}\text { perlakuan } \\
\text { (Pre op) }\end{array}$ & & & $11,39-25,27$ & 0,000 \\
$\begin{array}{l}\text { Setelah } 9 \\
\text { perlakuan } \\
\text { (post op) }\end{array}$ & 55,78 & 7,99 & & \\
\hline
\end{tabular}

1.7 Uji hipotesis III. Perbedaan antara pemberian breathing exercise dan insentif spirometri (kel.I) dengan breathing exercise convensional (kel.II) dalam meminimalisasi penurunan vital capasity paru.

Tabel 5.7 memperlihatkan selisih nilai rerata nilai VC pada pre dan post kelompok perlakuan (I) yang mendapatkan breathing exercise dan insentif spirometri adalah: 18,33, sedangkan pada kelompok perlakuan ( II ) yang mendapatkan hanya Terapi latihan adalah: 14,22. Analisis statistik $u j i$ beda Independent $t$ test pada masing - masing 9 subyek menunjukkan nilai $\mathrm{P}$ adalah 0,512. Karena nilai $P>0,05$ maka tidak ada perbedaan yang signifikan antara pemberian kombinasi breathing exercise dan insentif spirometri ( kel.I) dengan breathing exercise saja ( kel.II ), dalam meminimalisasi penurunan nilai prosen prediksi vital capasity paru pada pasien CABG fase I.

Tabel 1.7

Uji Independent t-Test uji beda selisih nilai kelompok I dan Kelompok II terhadap Penurunan nilai VC paru

\begin{tabular}{|c|c|c|c|c|}
\hline $\begin{array}{c}\text { Jenis } \\
\text { Perlakuan }\end{array}$ & $\mathbf{n}$ & Mean & $\mathbf{T}$ & $\mathbf{P}$ \\
\hline $\begin{array}{l}\text { Breathing } \\
\text { exercise dan } \\
\text { insentif } \\
\text { spirometri } \\
\text { (Kel.I) }\end{array}$ & 9 & 14,22 & & \\
\hline $\begin{array}{l}\text { Terapi Latihan } \\
\text { ( Kel.II) }\end{array}$ & 9 & 18,33 & 0,671 & 0,512 \\
\hline
\end{tabular}

\section{Pembahasan}

Penelitian ini merupakan penelitian eksperimental dengan tujuan untuk mengetahui perbandingan efek terapi kombinasi breathing exercise dan insentif spirometri dibandingkan dengan hanya breathing exercise dalam mencegah penurunan vital capasity paru (VC).

Pasien pro CABG dilakukan assessment dan fisioterapi pre operasi yang meliputi anamnesis, pemeriksaan fisik dan pengukuran fungsi paru salah satunya vital capasity (VC) dengan spirometri. Bagi pasien yang memenuhi kriteria inklusi, akan dimasukkan kedalam salah satu kelompok secara acak, untuk kemudian diberikan intervensi berupa kombinasi breathing exercise dan insentif spirometri atau hanya terapi breathing exercise saja sesuai dengan kelompoknya masingmasing, kemudian setelah enam kali 
fisioterapi atau hari keenam pasca operasi dilakukan pengukuran fungsi paru atau vital capasity

\subsection{Karakteristik subyek penelitian}

Pada penelitian ini jumlah subyek penelitian adalah sebanyak 18 orang dimana dijumpai laki-laki lebih banyak dibandingkan perempuan yaitu $83 \%$ laki-laki $(n=15)$, dan $17 \%$ adalah perempuan $(n=3$.$) , laki - laki$ terbanyak pada kelompok I yaitu 8 orang. Rerata usia subyek pada penelitian kelompok I adalah 56 tahun (SD $=3,77$ ) dan kelompok II (rerata $57 \pm 6,34$ tahun) dengan rentang usia 48 - 61 tahun. Rentang usia yang terbesar adalah 51-60 tahun sebanyak 10 orang $(56 \%)$ terdapat 7 orang $(78 \%)$ pada kelompok I. Menurut Ulfa.A(2001) resiko penyakit jantung koroner meningkat seiring usia. Semakin tua, semakin menurun efektivitas organ-organ tubuh, termasuk sistem kardiovaskulernya. Lebih dari 80 persen penderita jantung koroner berusia di atas 60 tahun. Lakilaki cenderung lebih cepat terkena dibandingkan perempuan, yang risikonya baru meningkat drastis setelah menopause.

Tinggi badan responden kelompok I (rerata $158,67 \pm 5,45 \mathrm{~cm}$ ) sedangkan kelompok II (rerata 157,89 $\pm 6,27 \mathrm{~cm})$, hal ini sesuai dengan fisiologi bahwa semakin tinggi umur akan semakin rendah tinggi badan dan juga nilai prosen prediksi fungsi paru.

\subsection{Pengaruh kombinasi breathing exercise dengan insentif spirometri (Kel.I) dalam mencegah Penurunan Nilai VC pada pasca CABG.}

Rerata nilai VC pada 9 subjek diukur dengan spirometri, di awal penelitian adalah 73,78 (pre op). Setelah mendapatkan terapi kombinasi breathing exercise dengan insentif spirometri Selama 6 hari atau 6 kali pertemuan, nilai rerata VC menurun menjadi 59,56. Rerata penurunan nilai VC setelah 6 hari terapi breathing exercise dengan insentif spirometri adalah 14,22.

Analisis statistik dengan $u j i ~ t$ dependen menunjukkan nilai $\mathrm{p}=$ 0,002 , karena nilai $\rho<0,05$ disimpulkan bahwa ada perbedaan yang signifikan dalam hal rerata nilai FVC sebelum perlakuan ( sebelum operasi) dan setelah enam kali mendapatkan perlakuan terapi kombinasi breathing exercise dengan insentif spirometri (pasca operasi).

Menurut Gosselink (2005) menyatakan bahwa operasi torak dan abdomen menyebabkan penurunan fungsi paru hingga $55 \%$ pasca operasi. $\mathrm{Hal}$ ini disebabkan oleh efek anaestesia, nyeri sekitar luka operasi, disfungsi diafragma, disfungsi otot-otot pernapasan dari kesemuanya itu akan berkontribusi untuk terjadinya atelektasis hingga menyebabkan penurunan vital capasity paru.

Penelitian yang dilakukan oleh Guemaraes.et.al (2006). Penambahan insentif spirometri dalam intervensi fisioterapi pada pasca bedah torak, telah terbukti dapat mencegah komplikasi komplikasi paru dan mengurangi lama perawatan di rumah sakit. Irawati ch (1996) menyatakan bahwa tahap awal latihan penguatan dan ketahanan otot- otot pernapasan pada pasien pasca operasi dapat diberikan dengan bantuan alat insentif spirometri dan latihan mobilisasi untuk meningkatkan vital capasity paru. Menurut penelitian overend J.et al. (2001) Insentif spirometri dan latihan napas dalam efektif untuk mencegah komplikasi paru pada pasca bedah torak dan perut. Freitas (2007) Latihan dengan tehnik insentif spirometri mengurangi angka kematian dan kesakitan akibat komplikasi paru pada pasca bypass graft.

Penulis beranggapan dengan pemberian terapi insentif spirometri yang dikombinasikan dengan breathing exercise akan memberikan fasilitasi yang kuat untuk mendapatkan kontaksi otot-otot pernapasan. Kontraksi volunter otot-otot pernapasan dapat 
diperoleh melalui mekanisme stimulasi central dan stimulasi perifer. Hasil penelitian ini menunjukkan adanya efek terapi kombinasi breathing exercise dengan insentif spirometri terhadap meminimalisasi penurunan vital capasity paru dengan nilai $p<0,002$.

\subsection{Pengaruh breathing exercise (Kel.II) Dalam mencegah penurunan nilai VC pada pasca CABG.}

Rerata nilai penurunan VC pada 9 subjek di awal penelitian adalah 74,11 setelah enam hari pasca operasi atau 6 kali fisioterapi dengan breathing exercise, nilai reratanya menjadi 55,78 . Rerata penurunan nilai VC setelah diberikan terapi breathing exercise adalah:18,33. Analisis statistik uji $t$ dependen menunjukkan nilai $\mathrm{p}=$ 0,000, karena nilai $\rho<0,05$, disimpulkan bahwa breathing exercise mempunyai efek terhadap meminimalisasi penurunan nilai VC pada pasien pasca CABG .

Menurut Nurbasuki (2008) masalah yang timbul pada fase awal pasca operasi adalah nyeri sekitar dada, sesak napas, sekret sulit untuk dikeluarkan dan keterbatasan aktivitas. Efek dari anaestesia, nyeri luka operas, posisi supin lying, respirasi yang monoton dan dangkal akan menyebabkan penimbunan secret di saluran napas atau atelektasis, hal ini menyebabkan penurunan fungsi dan nilai VC paru. Sema. et al. (2006) Latihan pernapasan dan mobilisasi sedini mungkin sangat efektif untuk mengurangi atelektasis, radang paru dan komplikasi paru lainnya pada pasien pasca operasi CABG. Sebagian besar literatur mengatakan Intervensi fisioterapi berupa deep breating exercise pada pre dan pasca operasi akan mengurangi komplikasi atelektasis dan meningkatkan fungsi dan vital capasity paru.

Deep breathing exercise dikombinasikan dengan terapi latihan setelah operasi coronary arteri bypass graft (CABG), telah dilaporkan efektif untuk mengurangi komplikasi paru.
Penelitian Westerhal, et al.(2005) Menemukan bahwa tindakan fisioterapi pada pra operasi dan pos operasi secara signifikan menurunkan atelektasis dan meningkatkan nilai vital capasity paru dibanding dengan kelompok yang tidak mendapatkan perlakuan deep breathing exercise.

Hasil-hasil penelitian di atas menunjukkan bahwa deep breathing exercise berpengaruh dalam meminimalisasi penurunan vital capasity paru pada pasca operasi. Efektifnya kerja otot pernapasan, berkurangnya kecemasan dan nyeri, bersihnya saluaran napas ini akan mengurangi tahanan udara, membuat proses inspirasi dan ekspirasi lebih efektif sehingga penururunan vital capasity paru akan lebih minimal .

\subsection{Beda pengaruh perlakuan kelompok I dengan perlakuan kelompok II dalam mencegah penurunan vital capasity paru.}

Pada penelitian ini uji beda memperlihatkan selisih penurunan nilai rerata VC pada pre dan post kelompok perlakuan ( I ) yang mendapatkan deep breathing exercise dan insentif spirometri adalah 15,33, sedangkan pada kelompok perlakuan ( II ) Yang mendapatkan hanya deep breathing exercise adalah 18,33 , analisis statistik Independent $\mathrm{t}$-Test pada masingmasing 9 subyek menunjukkan nilai $p$ adalah 0,512. Karena nilai $p>0,05$ maka tidak ada perbedaan yang signifikan antara pemberian insentif spirometri dan deep breathing exercise ( kel.I ) dengan deep breathing exercise saja ( kel.II ), dalam mencegah penurunan nilai prosen prediksi vital capasity .

Meskipun kedua kelompok perlakuan tersebut tidak ada perbedaan yang signifikan, tetapi selisih rerata nilai antara kelompok Perlakuan I (IS dan BE) dengan Kelompok II (BE) ada sebesar 3 dimana kelompok perlakuan I ( IS dan $\mathrm{BE}$ ) lebih baik. Hal ini kemungkinan dengan pemberian terapi kombinasi IS dan BE akan memberikan fasilitasi lebih 
besar karena adanya rangsangan dua arah yaitu melalui saraf tepi (perifer) dan Syaraf pusat (sentral). Hal ini dapat menjadi pertimbangan bagi kita dalam melakukan intervensi fisioterapi terhadap meminimalisasi penurunan vital capasity atau nilai VC, walaupun kemungkinan masih ada kontroversi sesuai dinamika ilmu pengetahuan.

\section{KESIMPULAN}

Berdasarkan dari pembahasan diatas dapat disimpulkan sebagai berikut, terdapat pengaruh yang signifikan pada kombinasi pemberian insentif spirometri dan breathing exercise dalam menghambat penurunan vital capasity paru pada pasca CABG fase I, Terdapat pengaruh yang signifikan pada pemberian breathing exercise dalam menghambat penurunan vital capasity paru pada pasca CABG fase I, Tidak terdapat perbedaan yang bermakna antara perlakuan kombinasi insentif spirometri dan deep breathing exercise dengan deep breathing exercise saja terhadap menghambat penurunan vital capasity paru pada pasca CABG fase I.

\section{DAFTAR PUSTAKA}

Adam Malik, RSUP, 2011, Laporan Evaluasi Kinerja Rumah Sakit Umum Pusat H.Adam Malik tahun 2011. Medan

Adriskanda, B. Yunus, F. Setiawan, B. 1997. Perbandingan nilai kapasitas Difusi paru antara orang yang terlatih dan tidak terlatih. Jurnal Respirologi Indonesia, 17, 76- 83.

Alsagaf.dkk.2002. Dasar-dasar IImu Penyakit Paru .Surabaya: Airlangga Press.

Anonim. 2010. Laporan Tahunan Cardiac Vascular Care Unit RSUP H.Adam Malik Tahun 2010. Medan

Atmadja DS, Doewes M. 2004. ACSM: Panduan Uji Latihan Jasmani dan Peresepannya.Edisi 5, EGC. Jakarta.
Bahri T.2009, Penyakit jantung koroner beserta penanggulangannya, USU, Medan.

Despopoulos,AMD.Color Atlas of Physiology.edisi 5, New York:Thieme, 2003.

Freitas FR, 2007. Incentive spirometry for preventing pulmonary complication after coronary artery bypass graft, Brazil Centro Physical Therapy Department, Parana, Brazil

Ganong WF. 2003, Fisiologi Kedokteran, editor, H.M.Djauhari, EGC, Jakarta, P.621-670.

Gosselink.R. .2005, Respiratory Muscle Assesment, Europa Respiratory Society journals.

Guimaraes. et al, 2006. Incentive Spirometry For Prevention of Post Operative Pulmonary Complication in Upper Abdominal Surgery, Department of Aesthetics and Cosmetology, CESUMAR,Brazil.

Irawati. ch,2005, Program Fisioterapi Pada Kasus Pulmonal, RSAB Harapan Kita,Jakarta

Kusmana D, 1997, Olahraga Bagi Kesehatan Jantung, Cetakan pertama, Balai Penerbit FKUI, Jakarta.

Kusmana.D. dkk. 2003. Simposium Rehabilitasi Jantung Indonesi II, Indonesia heart Association, Jakarta.

Mulyono D.1997. Rehabilitasi pada Penyakit Paru Obstruktif Menahun. CDK,114:p.33-36. Jakarta

Nurbasuki,2010, Problematik Fisioterapi pada Kasus Respirasi, Universitas Indonusa Esa Unggul Jakarta.

Overend T.J, Anderson C.M, Lucy D, Jonson B.I, 2001. The Effect of Incentive Spirometry on Postoperative Pulmonary Complications. Chest Journal.chestpubs.org；120:3:971978.

Pocock, SJ, 2008. Clinical Trial A Practical Approach, John wiley \& Sons, England 
Rhoades,RA,2006. The Control of Ventilasi and Mechanics of Breathing, Medical Physiologi, lippin cott, p. $363-374$.

Saunders WB,2006. Pulmonary Ventilation.in: Guyton, Hall.Text Book of Medical Physiology . 11 th. Ed .New York. P. 477 - 545.

Sema S.et al.2006. Active Cycle of Breathing Techniques and Incentive Spirometri in Coronary Artery Bypass Graff Surgery. Journal.Fyzioterapy rehabilitation.17 (2). Turki P.61-69

Ulfa.A. 2001. Buku Ajar Kardiovaskuler. Bidang diklat National Cardiovascular Center Harapan Kita.Jakarta

Umar N.2004. Sistem Pernapasan dan Suctioning Pada Jalan Napas. Bagian Anestesiologi Fk.USU.RSAM.Medan.

Westerhal et al, (2005), Chest Fisioterapy for preventing Pulmonary Complication, Coruna hospital, Spanyol.

Wikipedia.org. Praktek klinik insentif spirometri . diakses: 26 Desember 2011. Diunduhdari: file://C:/Users/Admin/Pictures/kar ya\%20amii/animee/spiro.htm 